\title{
A World Leader in Medicine
}

\author{
Omar Mousa.
}

About the Author: Omar Mousa is a second year internal medicine resident at SUNY Upstate Medical University, Syracuse - New York - USA. The internal medicine program is of 3 years duration. He is a recipient of the Gold Foundation Humanism and EXcellence in Teaching Award for the year 2013.
Submission: Dec 19, 2013 Acceptance: Feb 11, 2014
Professor Anna Suk-Fong Lok, MD is the Alice Lohrman Andrews Research Professor in Hepatology, Director of Clinical Hepatology, and the Associate Chair for Clinical Research in the Department of Internal Medicine at the University of Michigan Health System. Dr. Lok obtained her medical degree from the University of Hong Kong in 1977 and her hepatology training under the late Dame Sheila Sherlock at the Royal Free Hospital in London, UK in 1982-83. She rose through the ranks at the University of Hong Kong until she moved to the United States in 1992. More than 30 fellows and junior faculty from all over the world have been trained by Dr Lok. She has received many awards throughout her career, including the Distinguished Scientist Award from the Hepatitis B Foundation, the Distinguished Women Scientist Award from the American Gastroenterological Association and the Distinguished Service Award from the American Association for the Study of Liver Diseases. Dr. Lok is the true triple threat having received awards from the University of Michigan for research excellence in 2011, distinguished mentor in 2012, and clinical excellence in 2013 (Anna Suk-Fong Lok. 2013. Available from: http://www.uofmhealth.org/profile/425/ anna-suk-fong-lok-md. Cited 2013 Dec 18; Councilor 2013-2015 - Anna Suk-Fong Lok. 2013. Available from: https://www.aasld. org/aboutus/leadership/Pages/lok.aspx. Cited 2013 Dec 18).

Dr. Lok's research focuses on the natural history of hepatitis B and $C$ and their pathogenesis and treatment. She also focuses on the prevention of liver cancer. Her research receives funding from the National Institute of Health, as well as multiple pharmaceutical companies and federal and private foundations. She has more than 350 publications on viral hepatitis and liver diseases. She is also the coauthor of the American Association for the Study of Liver Diseases (AASLD) guidelines on Hepatitis B. Dr. Lok served as an Associate Editor of Hepatology, a Co-Editor of the Journal of Viral Hepatitis, and a Senior Associate Editor of Gastroenterology. Dr. Lok is currently a Councilor for the AASLD.

I asked Dr Anna Lok if she could tell the readers of the IJMS and myself about her journey in the field of medicine and scientific research. She was very happy to share her great experience with us. Here is our interview:
Figure 1. Anna Suk-Fong Lok, MD, FRCP.

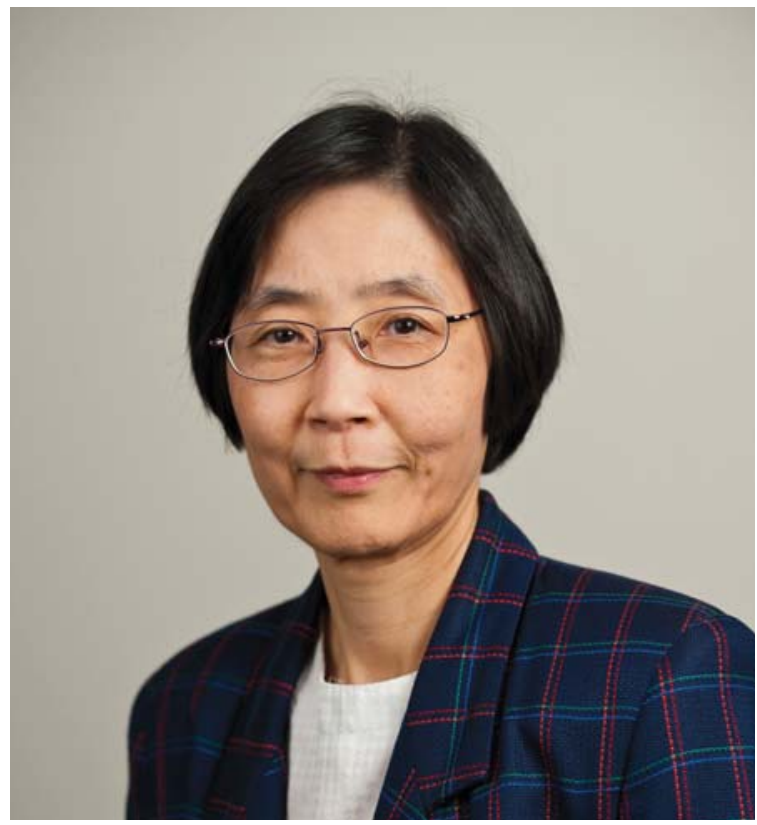

1- Dr Anna Lok, can you please tell us about yourself and what made you choose to become a doctor?

I grew up in Hong Kong and back then - more than 30 years ago, there were only two universities and very limited choices in career paths for students interested in science. I was interested in becoming a doctor because I wanted to work with people. I grew up in a conservative Chinese family. When I told my father I was planning to apply for medical school, he thought medicine was a profession for men and suggested I apply to nursing school instead. However, he was extremely delighted when I was accepted into the only medical school in Hong Kong at that time.

\section{2- What made you interested in Hepatology?}

My first rotation as a medical resident was gastroenterology. We had a lot of liver patients on the service. My attending was

${ }^{1}$ Resident Physician. SUNY Upstate Medical University - Syracuse - NY - USA. 
a hepatologist and an inspiring teacher, and we happened to have a visiting professor who was the head of the Liver Unit at UCSF, and who rounded on the service with me for 2 weeks. After that, I knew I wanted to be a hepatologist.

3- During your career, you had important achievements and great successes. Can you describe your most successful accomplishment?

I have my share of successes and failures - this is life. It is important that young people realize that those of us who have made it had our struggles and our failures also. So do not feel discouraged when things are not going your way. It is important to remember that our journey in life and our career is a marathon and not a sprint; there will be ups and downs and those who persevere will reach their destination. I am most proud of the accomplishment of all the fellows and junior faculty have trained and the outstanding Hepatology program I built at the University of Michigan. It is extremely gratifying to see that many of my mentees are now full Professors and heads of departments, to read their work in scientific journals, and to hear them lecture at scientific meetings.

4- What challenges did you have to overcome while pursuing your career including becoming a successful hepatologist, as well as coming to the United States?

I had very limited research experience when I arrived in London for my fellowship training. It took a long time and a lot of effort to convince others I was committed to research and I was trainable. I did not have any training in the US and I was not familiar with the health system so it took a while to learn how the health system works - I never had to bill my patients or had to understand health insurance before as Hong Kong has a socialized health care system at least back when I was working there. Despite having published more than 100 papers and having established myself as a promising young investigator, I had to prove myself all over again when I moved to the US and to show others that I could make it. I was very lucky in that many people extended a helping hand along the way.
5- What do you like the most about medicine?

We can help others and make a big impact on their health. Our work is never boring as each day brings different challenges and rewards. Although many complain that medicine is not a rewarding profession anymore, I disagree; we are well rewarded by that inner satisfaction that we improve the lives of others and most patients are appreciative.

6- In your opinion, what are the most important values the medical students and residents should learn for their future?

Recognize the impact of every little thing you do on your patients', and their family's, lives. Understand how privileged you are. While we cannot be perfect, we can and should always try our best. Also, remember that medicine is not just a science, it is also an art. Even when our hands are tied and modern medicine cannot save our patient's life, we can still make a difference by being compassionate and understanding.

7- Based on your research expertise, can you tell us why medical students should be encouraged to participate in medical research?

Without research, we would be practicing medicine like our great grandfathers did. Research stimulates us to ask questions and to find answers so we can provide better care to our patients. Even for those who do not plan to pursue an academic career, research trains us how to think, how to analyze problems, and how to interpret other people's work.

8- Finally, I would like to ask you for advice to help the new generation of trainees, including myself, to be great doctors and excellent practitioners?

Set your goals high but be focused, work hard, and never give up. Remember that medicine is not just a science but also an art. Learn how to communicate and how to listen, and always try to imagine if you or your loved one is on the other side of the consultation room.

\section{Acknowledgments}

None.

Conflict of Interest Statement t Funding

The authors have no funding, financial relationships or conflicts of interest to disclose.

Author Contributions

Write the manuscript: OM

Cite as:

Mousa 0. A World Leader in Medicine. Int J Med Students. 2014 Mar-Jun;2(2):76-7. 